\title{
TELEWORK AS THE DEVELOPMENT DIRECTION OF THE WAYS OF PROVIDING WORK BY AN EMPLOYEE IN THE CRISIS SITUATION
}

\author{
Marzena PYTEL-KOPCZYŃSKA ${ }^{1 *}$, Piotr OLEKSIAK ${ }^{2}$ \\ ${ }^{1}$ Czestochowa University of Technology, Faculty of Management; marzena.pytel-kopczynska@wz.pcz.pl, \\ ORCID: 0000-0001-8850-8586 \\ ${ }^{2}$ University of Lodz, Faculty of Economics and Sociology; piotr.oleksiak@uni.lodz.pl, \\ ORCID: 0000-0001-7889-396X \\ * Correspondence author
}

Purpose: The purpose of this article is to present the peculiarity of telework as a form of providing work relation in the crisis situation in the organisation.

Design/methodology/approach: The article demonstrates the term of telework, its legal regulations, advantages and disadvantages of telework as well as shows the results of empirical study concerning this issue in the period of Covid-19 pandemic. The article is based on the literature review in this scope and presents the results of secondary study relating to the telework in Polish companies during the pandemic.

Findings: The considerations presented in the article indicate that the epidemiological situation connected with coronavirus enforced the necessity to take immediate and efficient actions to implement telework widely, which got a big group of supporters both among employers as well as employees. It is likely that home office may be the main form of providing work relation, e.g. the office one, in the nearest future.

Originality/value: The value of this paper is theoretical. The possibilities of implementing remote work were presented in the paper concerning its advantages and limitations, with the particular consideration of Polish work market. The paper is original due to its multiaspect approach to the academic issue whereas the obtained results may be useful both for management practitioners as well as may be an inspiration for further research.

Keywords: telework, employee, pandemic, Covid-19, organization.

Category of the paper: Viewpoint, General review. 


\section{Introduction}

Covid-19 pandemic (being a crisis situation for the economy as well as economic organizations functioning in it) lasting for longer time caused the necessity to make significant changes in the way of work organization. Its consequence (arising from the necessity to provide health safety for employees) was that the companies moved to the mode of telework. The months of telework caused that it got a big group of supporters (both among employees as well as employers). Thus, home office may become the basic form of work provision, e.g. the office one (no matter how the epidemiological situation develops).

\section{The term of telework and its legal aspects}

The term of telework is not clear. Generally speaking, the term of remote work and telework refers to every form of remote work i.e. performed outside the employer's seat.

According to J. Messenger (Messenger, 2019), one of the ways to identify various forms of remote work is so called evolutionary perspective of information and communication technologies. Taking it into consideration, J. Messenger distinguishes three generations of telework. The first generation was connected with personal computers, landline telephones and faxes (their aim was to limit the time and cost of commuting by making it easier for employees to use these devices). In the case of the second generation, the remote work is perceived as a particular kind of work organization covering e.g. traditional office work, mobile work or virtual work but also type of flexible work such as - part-time work or flexi-time. On the other hand, the third generation of telework is mainly connected with the development of ITC technology (laptops, smartphones). Thanks to that, these devices become not only data processing devices but also communication devices (of course the permanent access to the Internet is also crucial) making it possible to create so called "virtual office".

The remote work may be regarded as a particular case of flexible work in the scope of four flexibility dimensions: time, duration of relations, localization and a form of agreement between an employee and an employer (Carnoy, 2000). In particular, it refers mainly to the place dimension because remote work is performed outside the employer's seat. It is also possible to organise remote work in which the time of work performance is also flexible. Due to the fact that the employer is interested in the effects of the work, and not the detailed control of its course, the flexibility refers also to the way of job performance and leaving the employee the significant freedom concerning the organization of the details of their own work. 
J. Nilles is regarded to be a creator of remote work. He conducted the first experimental project of telework in 1973 and defined it as work which makes it possible to send its effects with the use of information technologies such as telecommunication and computers instead of physical move of people who are to perform this work (Nilles, 1976).

The idea of remote work was spread by A. Toffler in a book The Third Wave and the futurologist F. Kinsman in the position Telecommuters (Szluz, 2013).

Taking into consideration legal regulations - pursuant to article 3 of the Act of 20 March 2020 on Particular Solutions connected with the Prevention, Counteraction and Fighting COVID-19, Other Infectious Diseases and Crisis Situations caused by them - the employer may order remote work to the employee in any moment. Should the employer fail to have organizational or technical possibilities to perform the work at home, the employer should provide the employee with the appropriate equipment necessary to perform the work (computer or telephone). The employee may also request to perform remote work. However, finalny the employer takes final decisions and the employee must submit to the employer's decision. Pursuant to the article of the act mentioned above the employer may withdraw the order to perform telework at any moment (the employee should be informed about such a possibility when he is directed to work).

The employer ordering some employees telework and at the same time refusing its performance to other employees should have objective prerequisites. Should the employee state that, according to him, there was discrimination, he may file the case to be recognized in court. During the proceedings the employer must give clear reasons which he used when he introduced the remote work only for selected employees.

Legal regulations do not specify any additional employees' priviledges in the provisions of law (referring to their remuneration, i.e. subsidy to the consumption of electricity or payment for the use of the Internet). Remote work is performed according to the same conditions as the work on the contract of employment and with the same remuneration as work in the company seat. The employer is not obliged to introduce any additional benefits connected with the remote work, it is only the will of the employer (such benefits should be regulated in the company regulations). Should the company fail to have a collective labour agreement, work or remuneration regulations, the issues of possible equivalents or benefits for remote work are settled by the superior with the employee individually. 


\section{Profits and limits connected with the performance of telework}

Recently the interest in performing telework has been growing. The key determinants of the increase in the interest in this form of performing work relation comprise (Sęczkowska, 2019, Szluz, 2013):

- For the employer - the increase in competitiveness, adaptation to the world trends and the needs of young generation, trying to reduce the costs of work organization, minimising the employees' absence, willingness to acquire high-qualified specialists to perform projects.

- For the employee - the willingness of greater work flexibility (flexibility of the workplace, adaptation of work time and rhythm to their own possibilities), willingness to limit the time of commuting and economic and psychological costs connected with it, possibility to combine professional work with private life and family, willingness to work in friendly conditions), willingness to avoid co-workers (the disliked ones).

According to Olejniczak, the main macroeconomic benfits of the remote work are (Olejniczak, 2000, pp. 19-20):

- Increase in the company efficiency and creating new workplaces in every region of the world.

- Decreasing the level of migrations to big cities.

- Easier competition for small and medium companies with big companies.

- Ecological profits.

- Increase in the demand for telecommunication services and teleinformattion innovations.

The main advantages of the remote work are (Furmanek, 2015, pp. 128-129):

- The possibility to organize the work time on your own (the employees decides when they want to do some work, control the course of its performance and decide how they do this task).

- The remote work lets the employees regulate the work burden themselves and adapt it to their own biorhythm.

- The remote work makes it possible to adapt the work to the personal style of private life.

- The increase in the signifance of the employee's responsibility for the result and for the process and applied technical means.

- The satisfaction of the work effects and work control increases.

- The remote work gives the possibility of better use of the employee's potential possibilies.

- The remote work offers the wider access to the differentiated labour market and eliminates communting to work. 
Whereas, the basic disadvantages of the remote work for the employee comprise (Janiec, Kreft, Piontek, 2006):

- The loss of the ability to relax.

- Distance from the health problems.

- Danger of workaholism.

- Addiction to the technical equipment.

- Lower promotion prospects (being outside the office, the employees cannot show their achievements.

- Work deorganization (no routine and orders may lead to inappropriate work organization).

- Lower access to trainings.

- Longer work day (telework may lead to the extension of the work day without remuneration).

The proper management of employees who perform such work by the managerial staff is an important element of the efficient performance of remote work by an employee. In practice such management should include the individual employee's situation, organization characteristics and the type of performed work. The typical activities covering such management comprise (CIOP, 2021):

- The detailed specification of tasks ordered to employees and the terms of their performance.

- Preparation of the individual work plan which should be discussed and agreed with the employee.

- The early identification of possible mental health problems appearing by employees performing remote work including addictions to technology, technostress, symptoms of fear or depression.

- Providing the employees with the possibilities of contact with immediate superior as well as urgent, regular feedback about the tasks performed by them and proposed changes in order to improve the efficiency as well as to submit positive opinions about performed work.

- Agreeing the unified system of informing about readiness to work and using it in practice.

- Dividing the bigger teams into smaller ones (in which everybody has clearly specified tasks and objectives, which increases the clarity of the employee's role and facilitates the cooperation).

- Preventing the work monotony by introducing the rotation of performed tasks and highlighting the meaning or wider context of their performance. 
- Encouraging the employees to share information about the difficulties in order to detect them early and to prevent the occupational burden and burnout.

- Permanent monitoring of employees' professional skills in order to delegate the tasks properly and specify the needs in the scope of employees' training.

On the other hand, main advantages of introducing remote work for an organisation are in fact:

- Being independent of the local labour market (in the case of applying the remote work system there is no limit of employing workers in the local labour market and the company mat search for workers in the territory of the whole country.

- Lower costs (the fewer people work in the office, the smaller the office may be and in connection with it the costs of renting the space are smaller).

- Greater flexibility (remote work enables to increase the employment without the necessity to introduce changes in the office organization).

- Relations with customers (remote work provides the fast access of the proper person to the customer which is performed independently of the time and place).

- Greater workers' discipline (remote work excludes coming late to work as you work at home in time appropriate for you). Additionally, there is no problem of sick leaves as workers staying at home may continue working.

Whereas the disadvanatges of telework for employers comprise:

- High initial costs (creating the telework position requires that the company bears high expenditures in the short time, e.g. purchase of equipment, software and payments for using telecomminucation links).

- Difficulties in motivating (in the situation when the worker is rarely seen, it is difficult to create the feeling of the company main aim and the financial motivation is the only form of motivation).

- Data protection (during the performance of telework the information concerning the company activity is not kept inside the company but is sent to the employee's house and back and in consequence, there is the risk of information leak during the communication process and it may be taken by the competition).

- Problems with calculating the efficient work time (the remote workers' remuneration is usually calculated according to the results of their work and not the time spent to perform it in order to avoid this problem). 
The social benefits are also important aspects of performing the work relation in a form of telework. They comprise (Szluz, 2013, pp. 259-263):

- The employment chances for the disabled and the reduction of expenses for benefits connected with it, e.g. disability pensions.

- Reduction of unemployment connected with the creation of workplaces (also in the regions which are not well developed economically and have high unemployment which results in decreasing the expenses on unemployment benefits).

- Increase in the competitiveness for the companies employing teleworkers.

- Improvement in the environment protection, e.g. by reducing the amount of emitted fumes by the cars of commuters or reducing the use of paper.

- Improvement of the safety on roads (fewer cars means the reduction in the number of communication accidents).

- Integration of labour market in the world scale.

- Improvement of the interpersonal relations.

- Improvement of the company and employees' productivity.

- Facilitating the competitiveness of small and medium companies with the big ones.

- Creating the possibility to accelerate the employment reorganization.

\section{The remote work in Polish companies in the light of study results}

The state of epidemy lasting for longer time (and due to that the change to the remote mode of work for numerous employees of Polish companies) caused a big interest in this issue of many researchers and scientists. Its consequence is the fact that there appear numerous studies and reports which assess various aspects of this form of work relation (both from the employers' and employees' point of view).

For example the report ${ }^{1}$ concerning the telework in the time of pandemic Covid-19 conducted in the Polish labour market (Dolot, 2020) shows that:

- Before pandemic the remote work was a rather rare phenomenon $-43 \%$ od the tested respondents worked at home only sporadically and 33\% never worked at home (only almost $17 \%$ worked 3-4 days at home).

- During the pandemic almost $86 \%$ of tested respondents started the remote work for five days a week and 9\% worked 3-4 days a week.

- According to the tested workers the positive consequences of the telework comprised mainly - time saving, work adaptation to personal needs and needs of the family, spending more time with family or combing the professional and personal obligations.

\footnotetext{
${ }^{1}$ The study was conducted on a group of 327 workers from big companies of the sector of services.
} 
- The negative consequences of the remote work comprise - the lack of direct contact with coworkers, erasing the border between work and private life, the feeling of being all the time at work, resignation of breaks at work or problems with concentration in the presence of other flatmates.

- According to the tested respondents, the basic problems of telework are - no social contacts, feeling of isolation, presence of children's at home (taking care of them and learning with them), fear and scare connected with the future (making it difficult for the worker to concentrate) or finally weak internet connection.

- The employers provided employees at first with the appropriate equipment and other tools of telework ( $83 \%$ of surveyed responses), the workers received current information about what happens in the company (77\%), the employers trained the workers to use the telework tools $(75 \%)$. Only $33 \%$ of respondents were trained to organize their own work.

- The respondents working remotely expressed at first fears for decreasing their remuneration (53\%), being dismissed from work (39\%), loss of current benefits (34\%) or the increase in the scope and amount of obligations (30\%).

- $40 \%$ of respondents stated that they want to work 1-2 days a week remotely, $36 \%$ telework on single days a week. Only $5 \%$ of workers wanted to work remotely for the majority of their work time.

Whereas, the study (Śliż, 2020) conducted in April 2020 among the employees of various organizations shows that:

- The respondents, in the scope of tasks performed during the telework, performed mainly the tasks connected with the communication with the company interested parties in a form of phone conversations or with the use of electronic mail and the tasks connected with the preparation of documents and the tasks connected with IT and e-teaching.

- $41 \%$ of the tested units declared that there are informal rules referring to remote work.

- A small number of organizations tested the possibility of remote work in case the crisis made it impossible to work in an office.

- The majority of respondents declared the choice of permanent working hours for work in an office (in the workplace) and flexible working time during pandemic.

- The respondents declared the amount of working time from 6 to 8 hours during pandemic.

- According to the respondents, the advantages of telework are - flexible working time, spending less time in the means of public transport and the possibility to join work with household chores.

- The limitations of remote work are - the lack of direct contact with superiors and the lack of concentration connected with the work at home and problems with separating work from family life. 
Besides, the survey ${ }^{2}$ concerning remote work during the pandemic Covid-19 conducted by K. Mierzejewska and M. Chomicki presents the following picture of the situation (Mierzejewska, Chomicki, 2020, pp. 35-42):

- Over $42 \%$ of the tested respondents had the provision of remote work included in the work relation as a basic or equal form of work provision (providing work in a remote form in a continuous way or at least one day a week). Less that $41 \%$ of respondents provided remote work less regularly and almost $17 \%$ of respondents did not provide remote work at all.

- The respondents indicated most often that their work provided in an office featured with the higher level of verve, dedication and preoccupation that when they provided it remotely.

- The reposndents claimed that the lack of social contacts was the greatest disadvantage of telework and the decrease in motivation - the smallest one.

- The employees of public companies felt the invonveniences in providing telework due to the lack of direct communication and cooperation (almost $74 \%$ of answers) much more often than the employees of private companies (less than $43 \%$ of indications). It may be justified by the use of more advanced communication solutions by private companies (which replaced direct relations in a better way). Additionally, the more efficient structure of processes and the organization culture connected with it, the aim of which is at first to perform the tasks efficiently, might affect this situation.

The service Live Career.pl also conducted the survey study in 2021 concerning the respondents' opinion about the remote work ${ }^{3}$. The results of this study showed:

- $69 \%$ of the surveyed claimed that the greatest challenge of the remote work was to dissociate from work after finishing the obligations as well as motivate themselves to work and communicate with the manager and co-workers.

- $51 \%$ of the surveyed liked to work remotely whereas $45 \%$ claimed that telework affected the life - work balance in a negative way.

- According to the surveyed, the biggest pluses of telework are flexibile work time and feeling of safety.

- Almost half $(40 \%)$ of the respondents believed that the communication with the manager and co-workers deteriorated at the remote work and $20 \%$ claimed that it was better. Additionally, according to $1 / 3$ of the surveyed the telework had a negative effect to the promotion prospects or the possibility to get a pay rise and $1 / 5$ of the surveyed noticed that it was easier to get them in such a mode of work.

\footnotetext{
${ }^{2}$ The study was performer with the use of CAWI method in the group of 215 respondents. Over $69 \%$ of respondents' employers were the companies without foreign capital and the other $31 \%$ - companies with the share of foreign capital. Over $79 \%$ of respondents' employers comprised provate companies and only $29 \%$ public companies.

${ }^{3}$ Over 700 respondents took part in the survey.
} 
After the end of pandemic $38 \%$ of the surveyed would like to continue working remotely but only $12 \%$ declared that they would leave their work if the employer did not let them continue teleworking. Additionally, $30 \%$ of the surveyed claimed that they would start work by the employer who would provide them with the opportunity to work remotely in the future.

\section{Conclusion}

It should be assumed that the remote work widely used at present will probably not finish with the end of the pandemic Covid-19. The organizations which want to compete at the market - in particular in various crisis situations - will have to launch telework. The use of telework will cause that the companies will decrease the office space (the decrease in costs connected with the service of offices) or that some processes will get accelerated or will be more effective (with the use of the appropriately selected tools for remote work). The employee will get additional financial means which were spent on commuting before and will also get some time. However, the organization will have to provide the employee with appropriate competences (especially concerning the knowledge of tools necessary for on-line work) so that the workers could provide the remote work efficiently. It will also require the remodelling of internal communication in organizations and training the employees in this area as well as introducing changes in their internal regulations.

\section{References}

1. Carnoy, M. (2000). Sustaining Flexibility: Work, Family and Community in the Information Age. Cambridge: Harvard University Press.

2. Dolot, A. (2020). Raport z badania dotyczacego pracy zdalnej $w$ czasie pandemii Covid-19. Retrieved from https://epale.ec.europa.eu/sites/default/files/praca_zdalna_w_ czasie_pandemii_covid-19_raport_anna_dolot_all_1.pdf, 18.10.2021.

3. Furmanek, W. (2015). Zalety i wady telepracy. Edukacja-Technika-Informatyka, No. 1(11), pp. 128-129.

4. Janiec, M., Czerniak, Kreft, T., Piontek, R. (2006). Prowadzenie działalności biznesowej z zastosowaniem telepracy - poradnik. Warszawa: PARP, pp. 66-67.

5. Messenger, J.C. (2019). Introduction: Telework in the 21 st century - an evolutionary perspective. In: J.C. Messenger (ed.), Telework in the 21st Century - An evolutionary perspective (pp. 1-34). The ILO Future of Work Series. Cheltenham: Edward Elgar. 
6. Mierzejewska, K., Chomicki, M. (2020). Psychospołeczne aspekty pracy zdalnej. Wyniki badań przeprowadzonych $\mathrm{w}$ trakcie trwania pandemii COVID-19. Zeszyty Naukowe, No 3(987). Uniwersytet Ekonomiczny w Krakowie, pp. 35-42, https://doi.org/10.15678/ ZNUEK.2020.0987.0302.

7. Nilles, J.M. (1976). The telecommunications - transportation trade off: Options for tomorrow. Wiley, p. 87.

8. Olejniczak, Z. (2000). Telepraca - nowa szansa na zatrudnienie. Polityka Spoleczna, No. 10, pp. 19-20.

9. Praca zdalna $w$ Polsce. Badanie opinii 2021. Available online https://mlodziwlodzi.pl/praca-zdalna-w-polsce-badanie-opinii-2021/, 18.10.2021.

10. Protasiuk, M. (2002). Telepraca - praca przyszłości? Retrieved from http://controlling.info.pl/artykuly/telepraca-praca-przyszlosci-,32.html, 18.10.2021.

11. Sęczkowska K. (2019). Konsekwencje psychospołeczne pracy zdalnej. Problemy Nauk Humanistycznych i Społecznych. Teoria i Praktyka, No. 2.

12. Szluz, B. (2013). Telepraca - nowoczesna elastyczna forma zatrudnienia i organizacji pracy. Szansa czy zagrożenie? Modern Management Review, vol. XVIII, no. 20(4), pp. 259263, https://doi.org/10.7862/rz.2013.mmr.59.

13. Śliż, P. (2020). Praca zdalna podczas epidemii COVID-19 w Polsce - wyniki badania empirycznego. E-mentor, No. 3(85), Retrieved from http://www.e-mentor.edu.pl/artykul/ index/numer/85/id/1474, 18.10.2021.

14. Ustawa z dn. 2 marca 2020 r. o szczególnych rozwiązaniach związanych z zapobieganiem, przeciwdziałaniem i zwalczaniem COVID-19, innych chorób zakaźnych oraz wywołanych nimi sytuacji kryzysowych. Dz.U. 2020, poz. 374 [the Act of 20 March 2020 on Particular Solutions connected with the Prevention, Counteraction and Fighting COVID-19, Other Infectious Diseases and Crisis Situations, Journal of Laws 2020, item 374].

15. Zasady organizacji pracy zdalnej przy komputerze. Available online https://m.ciop.pl/CIOPPortalWAR/file/91884/202103241318\&Zasady_organizacji_pracy _zdalnej_CIOP_PIB_2021.pdf, 18.10.2021. 